\title{
Characteristics of Functional Materials Recovered from Indonesian Mangroves (Sonneratia alba and Rhizhophora mucronata) Using Subcritical Water Extraction
}

\author{
Ratih Pangestuti ${ }^{1 *}$, Adane Tilahun Getachew ${ }^{2}$, Evi Amelia Siahaan ${ }^{3}$ and Byung Soo Chun ${ }^{2}$ \\ ${ }^{1}$ Research Centre for Oceanography, Indonesian Institute of Sciences (LIPI), Jakarta 14430, \\ Rep. of Indonesia \\ ${ }^{2}$ Department of Food Science and Technology, Pukyong National University, 45 Yongso-ro, \\ Nam-Gu, Busan 48513, Rep. of Korea \\ ${ }^{3}$ Research and Development Division of Maine Bio-Industry, Indonesian Institute of \\ Science (LIPI), West Nusa Tenggara 83552, Rep. of Indonesia
}

\begin{abstract}
Mangrove is the most productive ecosystem in marine environment, as it provides a unique habitat opportunity for many marine species and key goods and services for human beings. In Indonesia, mangroves are still considered as underexploited marine resources, and functional materials from Indonesian mangroves are not characterized yet. In this study, two mangroves Sonneratia alba and Rhizhophora mucronata from Kendari, were hydrolyzed using the subcritical water extraction (SCWE) system. Three different temperature conditions $\left(150-230{ }^{\circ} \mathrm{C}\right.$ with $40{ }^{\circ} \mathrm{C}$ increments) were applied to obtain the best functional materials. Mangroves hydrolysate was further analyzed for total sugar, protein, phenol content. The antioxidant capacity and functional material contents varied significantly based on the sample materials and extraction conditions, with $R$. mucronata hydrolyzed at temperature $230{ }^{\circ} \mathrm{C}$ showing the highest antioxidant activity. High-performance liquid chromatography (HPLC) analyses revealed high contain of phenolic acids in all mangroves hydrolisates especially $R$. mucronata fruit (RMF). Collectively, this study shows the potential of mangroves resources in Indonesia in Indonesia for different applications (food, cosmetics and pharmacy) using environmental friendly technology.
\end{abstract}

\section{Introduction}

Indonesia is endowed with huge potentials of marine areas and enormous marine organisms. These organisms must adapt to the extreme environmental marine conditions with a range of physical parameters which lead to the synthesis of biologically active materials. The diversity of marine plants containing biologically active materials represents

\footnotetext{
*Corresponding author: pangestuti.ratih@gmail.com
} 
a large alternative medical resource and potentially reduce the dependence on chemically synthesized medicines [1]. Since time immemorial, many marine plants are used in phytomedicine. Mangrove is a small tree or shrub that grows in coastal brackish or saline waters; these plants have been used in folklore medicine [2]. In accordance with the use of mangroves in traditional medicine, many scientific studies have shown pharmacological activities of active substances from mangroves [2, 3]. Mangroves contain a number of bioactive substances including phenolics, alkaloids, steroids, terpenoids and saponin [4].

Conventional extraction using organic solvent is the most common technique to obtain physiologically active substances from marine plants. Various organic solvents, such as ethanol, methanol, mixtures of ethanol-water mixtures, ethyl acetate, and acetone are commonly used for extraction of [5]. However, the massive, wide-scale use of organic solvents by a diverse range of global industries represents a serious threat to the environment and human health. Organic solvents are a major contributor to the overall toxicity potential associated with many industrial processes and to the waste generation of chemical industries. In order to minimizing solvent consumption, it is important to develop solvent-free processes. These techniques includes enzymatic, ultrasound, microwave assisted extraction, super critical $\mathrm{CO}_{2}$, and subcritical water extraction (SCWE). The SCWE process is an environmentally clean technique that can be used to recover bioactive substances from mangroves. In general, the SCWE process increases the yield of bioactive substances and their biological activities. In addition, SCWE exhibits a number of advantages such as its simplicity, reduced extraction time, lower cost of the extracting agent, and its environmental friendliness [5].

The objective of this study was to compare the effectiveness of subcritical water extraction (SCWE) from $150{ }^{\circ} \mathrm{C}$ to $230{ }^{\circ} \mathrm{C}$, from different mangroves part including Sonneratia alba leaves (SAL), Sonneratia alba fruit (SAF) and Rhizhopora mucronata fruit (RMF). In addition, total sugar, reducing sugar, protein, flavonoid, phenolic and saponin as well as antioxidant activities of various mangroves hydrolysates were investigated. Phenolic acid compositions of mangroves hydrolysates were also determined using highperformance liquid chromatography (HPLC).

\section{Materials and Methods}

\subsection{Materials}

Mangroves (Sonneratia alba leaves (SAL), Sonneratia alba fruit (SAF) and Rhizhopora mucronata fruit (RMF)) were collected from Bungkutoko, Kendari, Indonesia, in May 2017 (dry season) SAL; SAF and RMF were crushed into a powder with a particle size $<710 \mu \mathrm{m}$ and stored in $-20^{\circ} \mathrm{C}$. All the chemicals used in this study were of analytical grade.

\subsection{Subcritical water extraction}

Mangroves fine powder were placed in the subcritical water reactor and mixed with distilled water ( $\mathrm{pH}$ 7.2) at $\mathrm{S} / \mathrm{L}$ ratios 1:50. The reactor was closed and heated up to different temperatures $\left(150,190\right.$, and $\left.230^{\circ} \mathrm{C}\right)$. Each hydrolysis process was run for $600 \mathrm{~s}$. Mangroves hydrolysates were then collected, filtered under a slight vacuum through a Buchi vacuum pump V100 with F1113 grade filter paper, pooled, and lyophilized using freeze dryer, hydrolysates were stored at $-20{ }^{\circ} \mathrm{C}$ until further analysis. 


\subsection{Yield, $\mathrm{pH}$ and colour of mangrove hydrolysates}

The yield of mangroves hydrolysates was determined. The initial weight of mangroves $\left(\mathrm{W}_{\mathrm{mi}}\right)$ was obtained from the sample weight before loading into the reactor. The final weight of mangroves hydrolysates was obtained from the final dry weight of hydrolysates after freeze dried $\left(\mathrm{W}_{\mathrm{mf}}\right)$. The following formula was used for the calculation of yield: Yield: ${ }^{W m f} /{ }_{W m i} \times 100 \%$

Following hydrolysis process, $\mathrm{pH}$ of mangroves hydrolysates were measured using $\mathrm{pH}$ meter. The color characteristics of mangroves hydrolysates were determined using a reflectance tintometer (Lovibond RT Series, UK). The color values of HMH were expressed as lightness ( $\mathrm{L}^{*}$ value); green $(-)$ to red $(+)\left(\mathrm{a}^{*}\right.$ value); and blue $(-)$ to yellow $(+)$ (b* value).

\subsection{Total protein, sugar and reducing sugar}

Protein concentrations of mangroves hydrolysates were measured based on Lowry's methods. The samples were mixed with $5 \mathrm{~mL}$ of alkaline copper sulphate solutions $(1 \%$ $\mathrm{CuSO}_{4} .5 \mathrm{H}_{2} \mathrm{O}, 2 \%$ tartrate $\left.\left(\mathrm{KNaC}_{4} \mathrm{H}_{4} \mathrm{O}_{6}\right), 2 \% \mathrm{Na}_{2} \mathrm{CO}_{3}\right)$ at $1: 100$ ratio, and added with 0.5 $\mathrm{mL}$ of $1 \mathrm{~N}$ Folin-Ciocalteu reagent. Absorbance was measured at $660 \mathrm{~nm}$, total content was expressed as mg BSA per gram dried sample (mg/g). The total sugar content (g glucose/100 $\mathrm{g}$ dried mass) of mangrove hydrolysates was determined using phenol sulfuric acid method. The reducing sugar content ( $\mathrm{mg}$ glucose/g dried mass) of mangrove hydrolysate was measured using 3,5-dinitrosalicylic (DNS) colorimetric assay [1].

\subsection{Total phenolic, flavonoid, saponin and HPLC analysis}

Total phenolic content (TPC) and HPLC analysis of phenolic acids were measured following the method described in our previous study [1]. Meanwhile total saponin and flavonoid contents were measured according to the previous study with slight modifications $[6]$.

\subsection{Antioxidant activity}

Mangroves hydrolysates was mixed with of $100 \mu \mathrm{M}$ DPPH. The mixture was incubated in the dark for $30 \mathrm{~min}$ and the absorbance was measured at $517 \mathrm{~nm}$ using microplate readers [1]. The final results were expressed as $\mathrm{mg}$ Trolox equivalent per g dry weight (mg TE g-1 DW).

\section{Results and discussion}

In this study, the yield of mangrove hydrolysate obtained from SCWE at different temperature ranged from 15.13-30.70\% (Fig 1A), consistently decrease with increasing temperature. Many studies reported reduction of SCWE recovery yield at high temperature (above $180^{\circ} \mathrm{C}$ ) since many bioactive substances will be degraded at elevated temperatures. The $\mathrm{pH}$ values of mangroves hydrolysates were found to be acidic (3.79 to 5.58, Fig 1B). Previous studies have reported that a decrease in $\mathrm{pH}$ by heat treatment forms carbonyl compounds and organic acids because of the non-enzymatic browning of sugars and increases acidity due to autocatalysis [15]. In addition, basic amino acids, such as arginine, 
bind to sugars and participate in browning via the maillard reaction. As a result, the $\mathrm{pH}$ decreases as the soluble amino acids gradually decrease and acidic substances are produced [16].

(A)

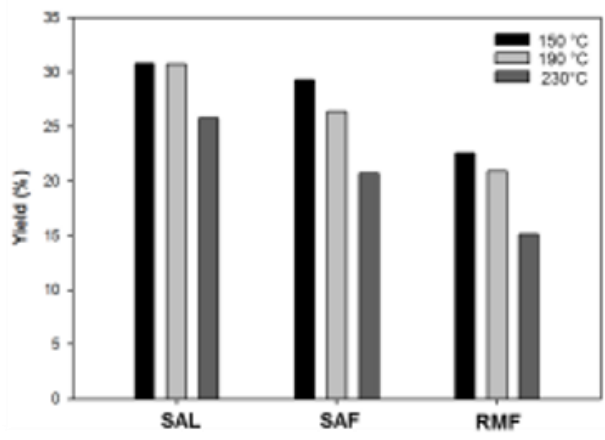

(B)

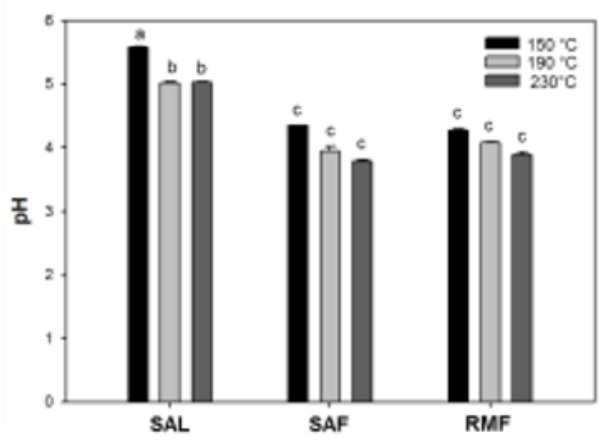

Fig 1. Recovery yield and $\mathrm{pH}$ of mangroves hydrolysates

Color is a vital factor in product appearance since it affects consumers' perceptions about flavor and quality of the product. The $\mathrm{L}^{*}, \mathrm{a}^{*}$, and $\mathrm{b}^{*}$ values represent one of the most popular instrumental methods for color measurement based on the primary parameters of lightness $\left(\mathrm{L}^{*}\right)$, redness $\left(\mathrm{a}^{*}\right)$, and yellowness $\left(\mathrm{b}^{*}\right)$. The color analysis of mangrove hydrolysate using the $\mathrm{L}^{*}, \mathrm{a}^{*}$, and $\mathrm{b}^{*}$ showed that mangrove hydrolyzed at higher temperature resulted in higher $\mathrm{L}, \mathrm{a}^{*}$, and $\mathrm{b}^{*}$ value. Lower $\mathrm{L}$ value at $150{ }^{\circ} \mathrm{C}$ might be correlated with the high sugar content obtained at lower temperature (Fig 2).

Table 1. Color values of the mangrove hydrolysate

\begin{tabular}{|c|c|l|l|l|l|l|}
\hline & Temp & \multicolumn{1}{|c|}{$\mathbf{L}$} & \multicolumn{1}{c|}{ a } & \multicolumn{1}{c|}{ b } & \multicolumn{1}{c|}{ Chroma } & \multicolumn{1}{c|}{ Hue } \\
\hline SAL & $150^{\circ} C$ & $6.73 \pm 0.15^{\mathrm{i}}$ & $12.14 \pm 0.42^{\mathrm{g}}$ & $5.25 \pm 0.32^{\mathrm{e}}$ & $13.22 \pm 0.51^{\mathrm{d}}$ & $66.64 \pm 0.55^{\mathrm{a}}$ \\
\hline & $190^{\circ} \mathrm{C}$ & $8.34 \pm 0.01^{\mathrm{h}}$ & $17.50 \pm 0.82^{\mathrm{d}}$ & $9.63 \pm 0.55^{\mathrm{de}}$ & $19.97 \pm 0.98^{\mathrm{cd}}$ & $61.18 \pm 0.25^{\mathrm{ab}}$ \\
\hline & $230^{\circ} \mathrm{C}$ & $12.32 \pm 0.23^{\mathrm{g}}$ & $16.67 \pm 0.56^{\mathrm{ef}}$ & $15.22 \pm 0.33^{\mathrm{cd}}$ & $22.57 \pm 0.63^{\mathrm{c}}$ & $47.59 \pm 0.35^{\mathrm{d}}$ \\
\hline SAF & $150^{\circ} \mathrm{C}$ & $12.94 \pm 0.21^{\mathrm{f}}$ & $20.39 \pm 0.42^{\mathrm{b}}$ & $16.78 \pm 0.34^{\mathrm{c}}$ & $26.40 \pm 0.54^{\mathrm{c}}$ & $50.54 \pm 0.01^{\mathrm{cd}}$ \\
\hline & $190^{\circ} \mathrm{C}$ & $22.18 \pm 0.16^{\mathrm{c}}$ & $22.30 \pm 0.06^{\mathrm{a}}$ & $28.69 \pm 0.15^{\mathrm{b}}$ & $36.33 \pm 0.08^{\mathrm{b}}$ & $37.86 \pm 0.22^{\mathrm{e}}$ \\
\hline & $230^{\circ} \mathrm{C}$ & $38.89 \pm 0.00^{\mathrm{a}}$ & $16.19 \pm 0.08^{\mathrm{f}}$ & $55.04 \pm 1.58^{\mathrm{a}}$ & $57.37 \pm 1.59^{\mathrm{a}}$ & $16.39 \pm 0.20^{\mathrm{g}}$ \\
\hline RMF & $150{ }^{\circ} \mathrm{C}$ & $14.56 \pm 0.06^{\mathrm{e}}$ & $22.26 \pm 1.07^{\mathrm{a}}$ & $14.69 \pm 0.88^{\mathrm{cd}}$ & $26.66 \pm 1.38^{\mathrm{c}}$ & $56.59 \pm 0.32^{\mathrm{bc}}$ \\
\hline & $190{ }^{\circ} \mathrm{C}$ & $15.17 \pm 0.46^{\mathrm{d}}$ & $19.41 \pm 0.45^{\mathrm{c}}$ & $19.47 \pm 0.28^{\mathrm{c}}$ & $27.49 \pm 0.51^{\mathrm{c}}$ & $44.91 \pm 0.25^{\mathrm{d}}$ \\
\hline & $230^{\circ} \mathrm{C}$ & $38.11 \pm 0.77^{\mathrm{b}}$ & $17.25 \pm 0.32^{\mathrm{de}}$ & $56.52 \pm 2.04^{\mathrm{a}}$ & $59.09 \pm 2.04^{\mathrm{a}}$ & $16.97 \pm 0.28^{\mathrm{f}}$ \\
\hline
\end{tabular}

In the present study, total sugar content recovered from SCWE process were ranged from $39.67 \pm 2.03$ to and $359.26 \pm 2.23 \mathrm{mg} / \mathrm{g}$ glucose equivalent and are presented in Fig. 2 . In SCWE process, the extraction temperature significantly affected the sugar content of mangroves hydrolysates. The optimum temperature for extraction of total sugar from mangroves were $150{ }^{\circ} \mathrm{C}$ with the value for SAL, SAF and RMF were 140.42 \pm 7.17 , $305.97 .55 \pm 6.10$ and $359.26 \pm 2.23 \mathrm{mg} / \mathrm{g}$ glucose equivalent. As the temperature increased from $150{ }^{\circ} \mathrm{C}$ to $190{ }^{\circ} \mathrm{C}$, the sugar content of mangroves hydrolysates were gradually decreased, and at $230{ }^{\circ} \mathrm{C}$, the total sugar drastically decreased. The result in the present study is consistent with the previous study that reported the rapid monosaccharide degradation at the highest temperature of SCWE process [7]. 

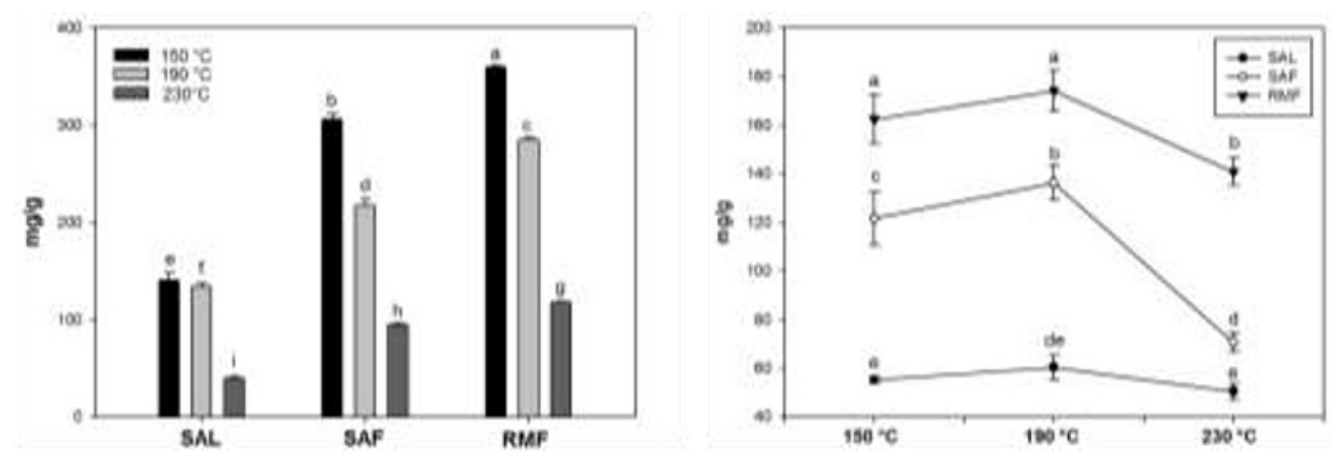

Fig. 2. Total sugar and reducing sugar

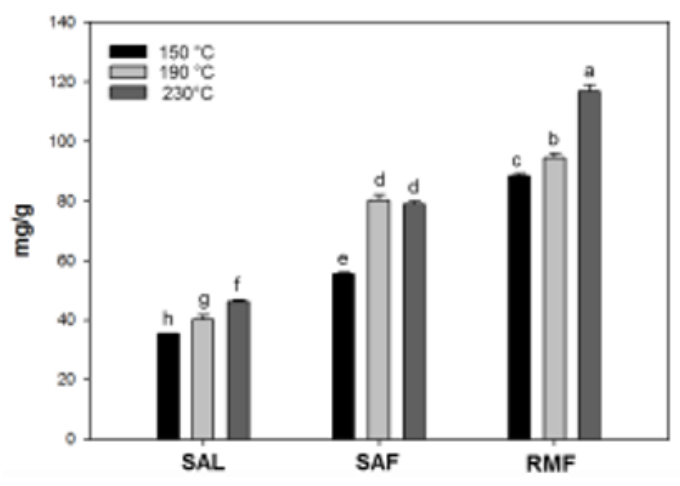

Fig. 3. Total protein

Crude protein content from mangrove hydrolysate obtained by SCWE are shown in Fig. 3. As the temperature of SCWE process increased from $150{ }^{\circ} \mathrm{C}$ to $230{ }^{\circ} \mathrm{C}$, protein content marginally increased from $35.30 \pm 0.20$ to $116.83 \pm 2.19 \mathrm{mg} \mathrm{BSA} / \mathrm{g}$. The highest protein yield $(116.83 \pm 2.19)$ was obtained from the $R$. mucronata fruit hydrolyzed at $230{ }^{\circ} \mathrm{C}$. Higher amount of protein observed at higher temperature in SCWE process could be related to the increased solubility of protein. The solubility of protein in mangroves hydrolysates are affected by intrinsic and extrinsic factors (such as $\mathrm{pH}$, ionic strength, solvent type, and hydrolysis temperature). In general, at lower temperature, protein has lower solubility due to robust aggregation through hydrophobic interactions [8]. Increase in temperature causes an increase in water ionization constant, which increases the protein yield. 


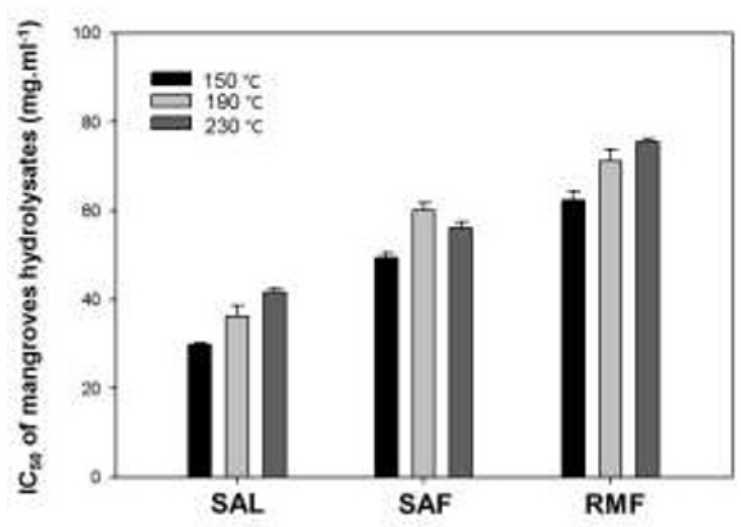

Fig 4. Antioxidant activities of mangrove hydrolysates

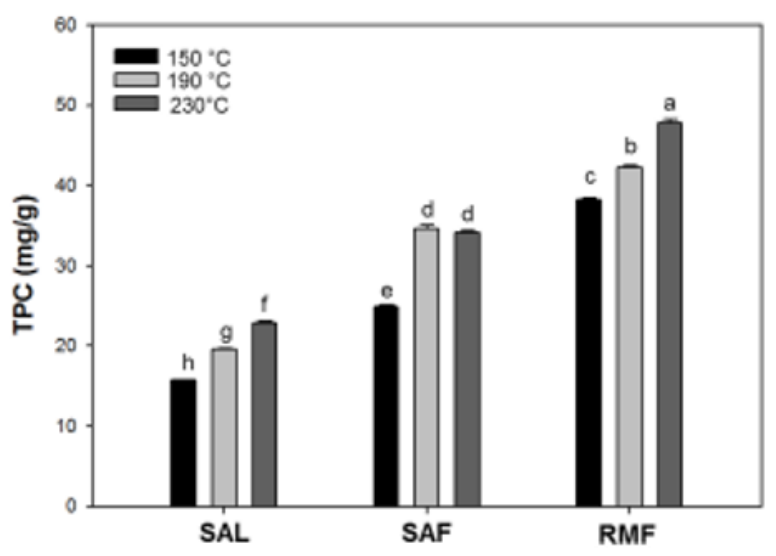

Fig 5. Total phenolic contents of mangrove hydrolysate

To determine the effect of temperature on the TPC, SCWE was carried out between 150 and $230^{\circ} \mathrm{C}$. The cumulative amount of TPC obtained during the SCWE extraction is shown in Fig. 4 which indicated that hydrolysis at $230^{\circ} \mathrm{C}$ contained the highest amount of TPC. One reason for the significant enhancement of TPC extracted in mangroves with increasing temperature was attributed to the decrease in water polarity (low dielectric constants) at higher temperature, which causes the increase in the solubilization capability of phenolic compounds [9]. As shown in the Fig. 4, the mangroves leaves have lower antioxidant activities as compared to the mangrove fruit. Meanwhile $R$. mucronata fruit hydrolysate showing higher radical scavenging activity compared to $S$. alba fruit. Antioxidant activity of plants hydrolysate depends on several factors including, the sample, processing method, the extraction method and time and the level of bioactive compounds such as phenolics groups. Based on several reports earlier, we assumed that strong antioxidant activity of mangrove hydrolysates is positively correlated with their phenolic contents $[10,11]$. The hydroxyl $(-\mathrm{OH})$ group bound to the aromatic ring acts as an electron donor, giving it to a free radical or other reactive species. This underlies the inhibition of reactive oxygen species formation and reactive oxygen species-mediated damage on lipid, protein and DNA $[5,12]$. In addition in Fig 5, we showed that $R$. mucronata fruit contain higher phenolic contents compared to $S$. alba fruit. 
Table 2. Phenolic acid constituents of mangroves hydrolysates obtained by SCWE (mg. g-1 dry material)

\begin{tabular}{|c|c|c|c|c|c|c|c|c|c|}
\hline Sample & Temp & $\begin{array}{c}\text { Gallic } \\
\text { acid }\end{array}$ & $\begin{array}{c}\text { Chloro- } \\
\text { genic } \\
\text { acid }\end{array}$ & $\begin{array}{c}\text { Gentisic } \\
\text { acid }\end{array}$ & $\begin{array}{l}\text { Procathe- } \\
\text { cuic } \\
\text { acid }\end{array}$ & $\begin{array}{c}p- \\
\text { hydroxy- } \\
\text { benzoic } \\
\text { acid }\end{array}$ & $\begin{array}{c}\text { Vanillic } \\
\text { acid }\end{array}$ & $\begin{array}{c}\text { Caffeic } \\
\text { acid }\end{array}$ & $\begin{array}{l}\text { Syringic } \\
\text { acid }\end{array}$ \\
\hline \multirow[t]{3}{*}{ SAF } & $150^{\circ} \mathrm{C}$ & 0.33 & 3.68 & ND & ND & ND & ND & 0.92 & 1.26 \\
\hline & $190^{\circ} \mathrm{C}$ & 1.45 & 1.97 & ND & ND & ND & ND & 0.94 & ND \\
\hline & $230^{\circ} \mathrm{C}$ & 8.59 & 11.40 & ND & ND & ND & ND & ND & ND \\
\hline \multirow[t]{3}{*}{ SAL } & $150^{\circ} \mathrm{C}$ & 1.23 & 4.42 & 24.30 & 6.68 & 3.89 & 2.10 & $\mathrm{ND}$ & ND \\
\hline & $190^{\circ} \mathrm{C}$ & 3.01 & 13.57 & 17.24 & 11.0 & $1 . .98$ & 5.66 & ND & ND \\
\hline & $230^{\circ} \mathrm{C}$ & 8.62 & 19.77 & 9.19 & 13.37 & 1.45 & 3.10 & ND & $\mathrm{ND}$ \\
\hline \multirow[t]{3}{*}{ RMF } & $150^{\circ} \mathrm{C}$ & 3.19 & 2.38 & 9.50 & 17.27 & 2.13 & ND & ND & $\mathrm{ND}$ \\
\hline & $190^{\circ} \mathrm{C}$ & 2.38 & 9.50 & 17.27 & 25.27 & 2.64 & ND & ND & $\mathrm{ND}$ \\
\hline & $230^{\circ} \mathrm{C}$ & 1.30 & 9.98 & 21.28 & 40.88 & 5.47 & ND & ND & ND \\
\hline
\end{tabular}

Table 2 shows the phenolic acid analysis of the mangrove hydrolysate using HPLC analysis. $R$. mucronata fruit was found to contain the highest phenolic acids compared to $S$. alba leaves and $S$. alba fruit. Phenolic acids profile in mangrove plants depends on a number of factor including mangrove species, mangrove parts, etc. Previous study has reported the presence of phenolic acid in mangrove, such as ferulic acid, vanillic acid, protocatechuic acid, chlorogenic acid, caffeic acid, benzoic acid, gallic acid, ellagic acid, epicatechin and catechin [13]. Our results are in good agreement with Alvarez et al. (2019), where tropical mangroves contain a variety of phenolic acids such as gallic acid, chlorogenic acid, gentisic acid, procathecuic acid, $p$-hydroxybenzoic acid, vanillic acid, caffeic acid, syringic acid. Phenolic acids in mangroves showed an increasing pattern as the SCWE temperature increase. The reason for the observed pattern could be attributed to the efficient extraction conditions in SCWE. It has been reported that SCWH increases the recovery of phenolic compounds from several kinds of plant resources, including mangroves. However, previous study also reported that raising the temperature of the SCWE process above certain temperature resulted in decreased amounts of phenolic compounds [14]. It was reported elsewhere that phenolic compounds decompose at high temperature [15]. Thus, extraction of phenolic compounds from mangroves at higher temperature required further study.

\section{Conclusion}

The results of the present study demonstrated that SCWE process enabled the recovery of functional materials (including sugar, protein, phenolic acids) from tropical mangroves with hydrolysis temperature at $230{ }^{\circ} \mathrm{C}$ were found to be the most optimum conditions. Compared to $S$. alba, R. mucronata was found to be more valuable source of phenolic acids with better antioxidant activity.

\section{Acknowledgement}

Pangestuti was supported by the National Research Foundation (Rep. of Korea) through the Postdoctoral Fellowship Program for Foreign Researchers 2017-2018. The authors acknowledge Dept. of Food Science and Technology, Pukyong National University, and Indonesian Institute of Science (LIPI) for all the support. 


\section{References}

1. Pangestuti, R.; Getachew, A. T.; Siahaan, E. A.; Chun, B.-S. J Appl Phycol 2019, 31, (4), 2517-2528.

2. $\quad$ Nabeelah Bibi, S.; Fawzi, M. M.; Gokhan, Z.; Rajesh, J.; Nadeem, N.; R.R., R. K.; R.D.D.G., A.; Pandian, S. K. Marine drugs 2019, 17, (4), 231.

3. Sawant, A.; Rodrigues, B. F.; Sardessai, Y., Anti-microbial and anti-cancer activity of Setosphaeria monoceras, an endophytic fungus associated with tropical mangrove plant. 2018.

4. Shanmugapriya, R.; Ramanathan, T.; Renugadevi, G. Int J Pharm Biol Arch 2012, $3,(2), 348-51$.

5. $\quad$ Pangestuti, R.; Siahaan, E.; Kim, S.-K. Marine drugs 2018, 16, (11), 399.

6. Jain, D.; Shrivastava, S., Estimation of Total Phenolic, Flavonoid and Saponin Content in Different Extracts of Butea monosperma Bark. 2017.

7. Meillisa, A.; Woo, H.-C.; Chun, B.-S. Food Chemistry 2015, 171, 70-77.

8. Watchararuji, K.; Goto, M.; Sasaki, M.; Shotipruk, A. Bioresource technology 2008, 99, (14), 6207-6213.

9. Budrat, P.; Shotipruk, A. Separation and Purification Technology 2009, 66, (1), 125-129.

10. Bandaranayake, W. M. Wetlands ecology and management 2002, 10, (6), 421-452.

11. Haq, M.; Sani, W.; Hossain, A.; Taha, R. M.; Monneruzzaman, K. Journal of Medicinal Plants Research 2011, 5, (17), 4112-4118.

12. Nurjanah, N.; Jacoeb, A. M.; Hidayat, T.; Shylina, A. International Journal of Plant Science and Ecology 2015, 1, (5), 182-189.

13. Martinez-Alvarez, I.; Leyva-Madrigal, K. Y.; Maldonado-Mendoza, I.; JaramilloFlores, M. E.; Gonzalez-Ocampo, H. Indian Journal of Pharmaceutical Sciences 2019, 81, (1), 181-187.

14. Vo Dinh, T.; Saravana, P. S.; Woo, H. C.; Chun, B. S. Separation and Purification Technology 2018, 196, 287-299.

15. Getachew, A. T.; Chun, B. S. Innovative food science \& emerging technologies 2016, 38, 24-31.

16. Ho, T.C; Chun, B.S. Journal of Food Science 2019, 84, (5), 1201-1207. 